\title{
Softening of drinking water by the pellet reactor - Effects of influent water composition on calcium carbonate pellet characteristics
}

Tang, Camilla; Hedegaard, Mathilde Jørgensen; Lopato, Laure ; Albrechtsen, Hans-Jørgen

\section{Published in:}

Science of the Total Environment

Link to article, DOI:

10.1016/j.scitotenv.2018.10.157

Publication date:

2019

Document Version

Peer reviewed version

Link back to DTU Orbit

Citation (APA):

Tang, C., Hedegaard, M. J., Lopato, L., \& Albrechtsen, H-J. (2019). Softening of drinking water by the pellet reactor - Effects of influent water composition on calcium carbonate pellet characteristics. Science of the Total Environment, 652, 538-548. https://doi.org/10.1016/j.scitotenv.2018.10.157

\section{General rights}

Copyright and moral rights for the publications made accessible in the public portal are retained by the authors and/or other copyright owners and it is a condition of accessing publications that users recognise and abide by the legal requirements associated with these rights.

- Users may download and print one copy of any publication from the public portal for the purpose of private study or research.

- You may not further distribute the material or use it for any profit-making activity or commercial gain

- You may freely distribute the URL identifying the publication in the public portal 


\section{Accepted Manuscript}

Softening of drinking water by the pellet reactor - Effects of influent water composition on calcium carbonate pellet characteristics

Camilla Tang, Mathilde Jørgensen Hedegaard, Laure Lopato, Hans-Jørgen Albrechtsen

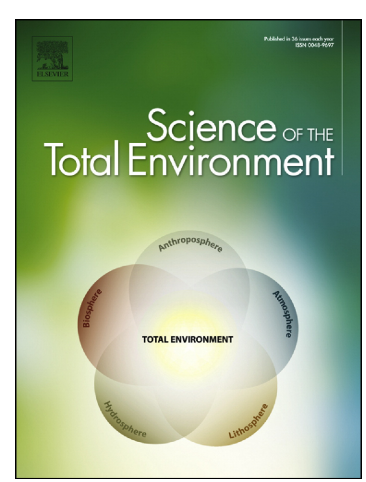

PII: S0048-9697(18)34040-3

DOI: doi:10.1016/j.scitotenv.2018.10.157

Reference: STOTEN 29060

To appear in: Science of the Total Environment

Received date:

6 July 2018

Revised date:

21 September 2018

Accepted date:

11 October 2018

Please cite this article as: Camilla Tang, Mathilde Jørgensen Hedegaard, Laure Lopato, Hans-Jørgen Albrechtsen, Softening of drinking water by the pellet reactor - Effects of influent water composition on calcium carbonate pellet characteristics. Stoten (2018), doi:10.1016/j.scitotenv.2018.10.157

This is a PDF file of an unedited manuscript that has been accepted for publication. As a service to our customers we are providing this early version of the manuscript. The manuscript will undergo copyediting, typesetting, and review of the resulting proof before it is published in its final form. Please note that during the production process errors may be discovered which could affect the content, and all legal disclaimers that apply to the journal pertain. 


\title{
Softening of drinking water by the pellet reactor - effects of influent water composition on calcium carbonate pellet characteristics
}

\author{
Camilla Tang ${ }^{a}$, Mathilde Jørgensen Hedegaard ${ }^{a}$, Laure Lopato ${ }^{b}$, Hans-Jørgen Albrechtsen ${ }^{a *}$
}

aDepartment of Environmental Engineering, Technical University of Denmark, Bygningstorvet 115, 2800

Kgs. Lyngby, Denmark. ( ${ }^{*}$ Corresponding author, e-mail: catang@env.dtu.dk)

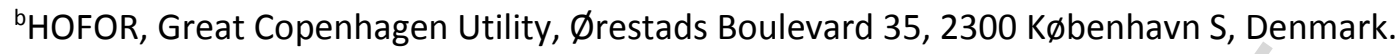

\section{Abstract}

Pellet softening of drinking water can provide aesthetic, socioeconomic and environmental benefits in areas with hard water. Calcium carbonate pellets are the main by-product from pellet softening and their characteristics determine their reuse potentials. We characterized pellets from a pilot-scale pellet reactor treating 16 water types at 8 Danish drinking water treatment plants to investigate the variations in pellet characteristics and how they depend on the influent water composition. The pellets consisted of up to 100 \% calcium as calcium carbonate, but contained often also impurities such as strontium, magnesium, iron and sodium each contributing with up to $1.3 \%$ of the pellet mass. Other elements, including heavy metals, accounted for less than $0.04 \%$ of the pellet mass. The quartz sand seeding material contributed with up to $15 \%$ of the pellet mass and can be a barrier for pellet reuse. Therefore, replacing this with calcium carbonate (limestone) seeding material increases the pellet purity. Modelling the chemical speciation indicated that elements not forming carbonates (e.g. potassium and magnesium), are only incorporated into pellets to a limited extent. The concentrations of strontium, magnesium, manganese, iron and nickel in the pellets had a strong positive correlation with the influent water concentration. Consequently, the pellet purity increases if the concentration of these elements is reduced in the water before softening by other treatment technologies. Potassium, arsenic and zinc showed no or only a weak correlation. The pellets precipitated as calcite, and had a reactivity of $\leq 25.7 \%$ and a specific surface area of $\leq 0.32 \mathrm{~m}^{2} / \mathrm{g}$, which limits the potential reuse in agriculture. The pellet mineralogy was independent of the investigated range of influent water quality and seeding materials. Including pellet quality when designing the softening 
process can improve pellet reuse, ultimately leading to a more environmentally sustainable drinking water supply.

Keywords: Calcite, calcium carbonate, chemical water treatment, residuals management, by-product reuse, drinking water treatment 


\section{Introduction}

It is increasingly important for water utility companies to ensure an environmentally sustainable drinking water production and distribution, while the produced water still meets regulatory guidelines in a costeffective manner (Marques et al., 2015). In areas with high water hardness, centralised drinking water softening can reduce the consumption of soap, detergents and other household chemicals and increase the service life and energy efficiency of e.g. kettles, coffee machines and other household appliances due to a reduction in calcium carbonate $\left(\mathrm{CaCO}_{3}\right)$ scaling. Godskesen et al. (2012) concluded that centralised softening became environmentally beneficial at a softening depth (i.e. hardness reduction) of $0.2 \mathrm{mmol} / \mathrm{L}$ $\left(1.2^{\circ} \mathrm{dH}\right.$, deutsche Härte) in the city of Copenhagen. Similarly, van der Bruggen et al. (2009) found a socioeconomic break-even at a softening depth of $0.5 \mathrm{mmol} / \mathrm{L}\left(2.8^{\circ} \mathrm{dH}\right)$ in Belgium. Consequently, centralised softening can provide aesthetic, socioeconomic and environmental benefits at a sufficiently high softening depth.

Water softening technologies include e.g. lime softening, pellet softening, ion exchange and membrane filtration (World Health Organization, 2011). Pellet softening is used in e.g. the Netherlands, Belgium and Sweden (Sydvatten, 2016; van Dijk and Wilms, 1991), and is currently being implemented for the first time in Denmark (HOFOR, 2017). In pellet softening the drinking water is treated in a fluidized bed reactor (upflow) where a chemical base (typically sodium hydroxide or calcium hydroxide) and a seeding material (typically quartz sand, garnet sand or $\mathrm{CaCO}_{3}$, limestone) are dosed (Figure 1). The $\mathrm{pH}$ increase initiates $\mathrm{CaCO}_{3}$ precipitation onto the seeding material, thereby forming pellets. As the pellets grow, they gravitate towards the bottom of the reactor where they are removed, and new seeding material is added (van Dijk and Wilms, 1991). Pellets are the main by-product from the softening process and by identifying reuse applications, they potentially represent a resource rather than being a waste product promoting circular economy. 
In Sweden, pellets are used to increase $\mathrm{pH}$ in acidified lakes (Sydvatten, 2016), while in Belgium they are used for soil amendment in agriculture (van der Bruggen et al., 2009), substituting commercial limestone products otherwise mined from sedimentary rocks. In the Netherlands, pellets are recycled as e.g. an ingredient in carpet production, sand substitute in concrete production, and garden fertilizer, but today pellets are also increasingly crushed into finer particles and reused as seeding material in the softening process (Aqua Minerals, 2016, 2015).

Pellet characteristics determine the technical feasibility of reuse applications. The influent water to the pellet reactor contains a number of elements that can precipitate with $\mathrm{CaCO}_{3}$ as impurities and their presence may be a barrier for pellet reuse. For instance, the iron concentration may not be too high if pellets are to substitute commercial $\mathrm{CaCO}_{3}$ products in the glass industry, whereas too much magnesium can limit the use in the production of Portland cement (Oates, 1998). In agriculture, the reactivity (determining how fast the pellets dissolve) should typically exceed $70 \%$ for commercial calcite products when measured by the Sauerbeck \& Rietz method (DLG, 2010; Sauerbeck and Rietz, 1985). Finally, impurities such as zinc, copper, cadmium, nickel and arsenic may be a barrier for use in e.g. agriculture, due to their toxicity (Mudhoo et al., 2012). The influent water composition also affects the physical properties of pellets since foreign ions can influence the polymorphic form (e.g. calcite versus aragonite) of the $\mathrm{CaCO}_{3}$ crystals (Waly et al., 2012), which can influence the pellet reuse potentials as well. Phosphate and iron can cause crystallization of undesired porous, 'fluffy' pellets, which break easily against the reactor walls (Ruhland and Jekel, 2004; van Dijk and Wilms, 1991). On the contrary, precipitation of the less stable aragonite polymorph is promoted in the industrial production of Precipitated Calcium Carbonate (PCC) and is used in high sales value markets such as paper coating, plastic and rubber production (Park et al., 2008).

In a traditional groundwater treatment plant with aeration and rapid sand filtration, pellet softening can be implemented before aeration as well as before or after rapid sand filtration. Other design parameters include the choices of chemical base, seeding material, reactor shape and upwards water velocity (van Dijk 
and Wilms, 1991). Despite extensive research on optimization of the softening process with respect to water quality (e.g. van Eekeren et al., 1994; van Schagen et al., 2008a, 2008b), optimization of pellets has got only little attention. Hammes et al. (2011) characterized the mineralogy of pellets in a study investigating bacterial colonization in pellet reactors, whereas Schetters et al. (2015) compared the efficiency of softening with garnet sand and crushed pellets as seeding material. However, none of the studies considered how the influent water composition and seeding material affect pellet characteristics.

The objectives of this study were: (1) to investigate the variations in pellet characteristics in pilot-scale experiments softening 16 water types at 8 Danish drinking water treatment plants (DWTPs); (2) to investigate how pellet characteristics depend on the influent water composition. In addition, we investigated how two types of seeding material, quartz sand and limestone, affect the pellet mineralogy. As a result, pellet quality and reuse can be considered when designing the softening process in a DWTP, ultimately promoting environmentally sustainable reuse of pellets in markets with high sales value.

\section{Methods}

\subsection{Pilot-scale investigations}

A pilot-scale pellet reactor was constructed for the investigations and set up at 8 Danish DWTPs treating 16 types of groundwater including raw groundwater, and water after aeration and rapid sand filtration (Table 1, Larsen et al., (2016)). The influent water hardness varied from $3.2 \mathrm{mmol} / \mathrm{L}\left(17.9^{\circ} \mathrm{dH}\right)$ to $6.1 \mathrm{mmol} / \mathrm{L}(34.1$ ${ }^{\circ} \mathrm{dH}$ ). The pilot-scale reactor had an inner diameter of $9.9 \mathrm{~cm}$ and a height of $6.7 \mathrm{~m}$. It was operated with a water flowrate of $0.6 \mathrm{~m}^{3} / \mathrm{h}$, which corresponds to an upwards velocity of $76 \mathrm{~m} / \mathrm{h}$. This is in line with fullscale pellet reactors, which are typically operated with upwards velocities ranging from 60 to $100 \mathrm{~m} / \mathrm{h}$ (Kiwa N.V., 2003). At Lindved DWTP the reactor was operated at $0.27 \mathrm{~m}^{3} / \mathrm{h}(34 \mathrm{~m} / \mathrm{h})$ due to a high fraction of fine particles in the quartz sand seeding material (0.3-0.6 mm, Saint-Gobain Weber), which is lower than the typical operating velocities for full-scale pellet reactors. Due to this, the pellet bed may not have been 
completely fluidized at Lindved DWTP. Sodium hydroxide $(\mathrm{NaOH})$ is commonly applied as chemical base in full-scale pellet reactors (Kiwa N.V., 2003) and $\mathrm{NaOH} 27.65 \%$ was used as chemical base in all pilot-scale investigations. $\mathrm{NaOH}$ was dosed through a single silicone pipe. In full-scale installations different systems are used for dosing $\mathrm{NaOH}$ for ensuring proper mixing of $\mathrm{NaOH}$ and the influent water (Kiwa N.V., 2003). Due to the small diameter of the pilot-scale reactor a single dosing point was assumed to be sufficient to ensure complete mixing of $\mathrm{NaOH}$ and water. The $\mathrm{NaOH}$ dosage was 112 to $210 \mathrm{mg} / \mathrm{L}$ depending on the initial water hardness; the effluent $\mathrm{pH}$ was between 8.5 and 9.2. The pellet reactor was started up with new seeding material and without pellets every time a new pilot-scale test was initiated. Over time $\mathrm{CaCO}_{3}$ precipitated onto the seeding material, forming pellets. Due to continuous removal of pellets, addition of new seeding material and the upwards flow conditions inside the reactor the pellets got stratified in the reactor over time, with decreasing pellet diameter with increasing reactor height (van Schagen et al., 2008b). The largest pellets were withdrawn from the bottom of the reactor 4-5 times each week and new seeding material was manually added to the top 1-2 times each week in order to maintain a fluidized bed height under $6 \mathrm{~m}$ and a pellet size of $1.0-1.2 \mathrm{~mm}$. Quartz sand (Dansand $29(0.18-0.50 \mathrm{~mm}), 33(0.18-$ $0.71 \mathrm{~mm}$ ) or 40 (0.25 - $0.71 \mathrm{~mm})$ from Dansand, or 'oven-dried quartz sand' ('ovntørret kvartssand', 0.3 $0.6 \mathrm{~mm}$ ) from Saint-Gobain Weber) was used as seeding material in all investigations, except at Frederiksberg DWTP where limestone (Lhoist 0.3-0.6 mm) was used in 3 investigations.

All the investigated DWTPs treat groundwater in a process train with aeration and rapid sand filtration, except at Thorsbro DWTP where the Solhøj well field has a naturally low concentration of iron $(<10 \mu \mathrm{g} / \mathrm{L})$, manganese $(<1 \mu \mathrm{g} / \mathrm{L})$ and ammonium $(<5 \mu \mathrm{g} / \mathrm{L})$, so the water is only aerated. Therefore, the quality of the aerated water from the Solhøj well field was categorized as 'after filtration' (Table 1). At Frederiksberg DWTP a pilot-scale air stripper was installed to remove chlorinated contaminants as part of another investigation. Pellet softening was conducted without stripping, after stripping of raw groundwater, and after stripping of treated filtrate (Table 1). At Lindved DWTP the inlet pipe to the pellet reactor had an 
opening as part of another investigation exposing the water to oxygen. Consequently, the influent water quality was categorized as after aeration (Table 1).

Four pellet samples from full-scale pellet reactors in the Netherlands were included in the analyses of pellet mineralogy and reactivity. These samples represented drinking water production from surface water and groundwater, 3 types of seeding material and softening with $\mathrm{NaOH}$ and $\mathrm{Ca}(\mathrm{OH})_{2}(\mathrm{Table} 2)$.

\subsection{Chemical composition of pellets and water}

Each pellet sample $(0.5 \mathrm{~g})$ was dissolved by microwave assisted acid digestion using the US EPA method 3051A (US EPA, 2007) with $9 \mathrm{~mL} 65 \%$ nitric acid $\left(\mathrm{HNO}_{3}\right)$ and $3 \mathrm{~mL}$ hydrochloric acid $(\mathrm{HCl})$. The seeding material of quartz sand did not dissolve. Seven pellet samples from Brøndbyvester and Marbjerg DWTPs were also partially dissolved in $0.5 \mathrm{M} \mathrm{HCl}$ at $10^{\circ} \mathrm{C}$ for $24 \mathrm{~h}$ during which 25.6 to $25.9 \%$ of the pellet mass dissolved.

Inductively coupled plasma mass spectrometry (ICP-MS, Agilent 7000x) was used to quantify lithium (Li), sodium $(\mathrm{Na})$, magnesium $(\mathrm{Mg})$, aluminium $(\mathrm{Al})$, phosphorus $(\mathrm{P})$, potassium $(\mathrm{K})$, chromium $(\mathrm{Cr})$, manganese $(\mathrm{Mn})$, iron (Fe), cobalt (Co), nickel (Ni), copper (Cu), zinc (Zn), arsenic (As), strontium (Sr), cadmium (Cd), lead $(\mathrm{Pb})$, tin $(\mathrm{Sn})$ and thallium $(\mathrm{Tl})$ in the solute. Calcium $(\mathrm{Ca})$ was quantified with inductively coupled plasma optical emission spectroscopy (ICP-OES, Varian MPX Axial), except for the pellet samples from Lejre, Thorsbro and Marbjerg (Brokilde well field) DWTPs which were analysed with ICP-MS.

Water was sampled in the influent and effluent of the pellet reactor, and was preserved with $\mathrm{HNO}_{3}$ and stored at $5{ }^{\circ} \mathrm{C}$ until analysis. $\mathrm{Ca}, \mathrm{Mg}$ and $\mathrm{Na}$ were quantified using ICP-OES, whereas the remaining elements were quantified by ICP-MS. Water samples from Marbjerg, Lejre and Thorsbro DTWPs were analysed by a commercial laboratory (Eurofins) using ICP-MS (ISO 17294m).

To investigate pellet formation during start-up of the pellet reactor and to ensure that the chemical composition of the analysed pellets represented the final by-products from long-term operation, the 
chemical composition of pellets was analysed during pellet formation from initiation of the pellet reactor until the withdrawn pellets had reached their final diameter. Pellets from Sønders $\varnothing$ DWTP were sampled and analysed with 2 or 3 days interval after the reactor start-up and until the reactor had been operating for 27 days.

\subsubsection{Statistics}

A D'Agostino-Pearson test was used to test if the pellet concentrations were normally distributed. The correlation between the influent water composition and pellet concentration was investigated using a Pearson's correlation coefficient for normally distributed data only and linear regression models were fitted for strongly correlated data. Since impurities were not expected in pellets unless present in the influent water, the linear regression model was fitted through the origin. Outliers were not removed prior to linear regression. The correlation between influent water composition and pellet concentration was tested with a Spearman's rank coefficient for data that were not normally distributed.

\subsubsection{Chemical speciation}

The chemical speciation in the water phase inside the reactor was modelled for Dalum DWTP using the software PHREEQC version 3.4.0-12927 (Parkhurst and Appelo, 2013). The chemical speciation in the bottom part of the reactor was modelled using the influent water composition. $\mathrm{pH}$ was calculated to 9.8 based on the addition of $126 \mathrm{mg} \mathrm{NaOH} / \mathrm{L}$ to the influent water quality with an initial $\mathrm{pH}$ of 7.3 and an initial alkalinity of $6.1 \mathrm{mmol} / \mathrm{L}$. In the upper part of the reactor it was modelled using the effluent water quality and $\mathrm{pH}$ (8.9). The influent water was raw groundwater without any content of free oxygen.

\subsubsection{Influence of seeding material}

The mass of the pellet samples included the seeding material, but since the quartz sand seeding material did not dissolve during sample preparation and it was not included in the ICP-MS and ICP-OES analyses, which adds some uncertainty to the calculated concentrations. To investigate this, undissolved seeding material from the pellet samples 'Brokilde', 'Lejre', 'Solhøj' and 'Havdrup' were dried and weighed. In general the seeding material constituted less than $2.5 \%$ of the total pellet mass. The pellets from 'Brokilde' 
were smaller, and as a result the seeding material constituted $15 \%$ of the pellet mass, leading to a decreased accuracy when comparing the quantified concentrations in pellet samples from different DWTPs. Future studies should quantify the seeding material after sample preparation to adjust concentrations for the mass of the seeding material. Since the limestone seeding material dissolved during sample preparation, the quantified concentrations in these pellets may have been affected if the seeding material contained impurities.

\subsection{Particle size distribution, reactivity, mineralogy and specific surface area}

The pellet particle size distribution was determined by sieve analyses (DIN ISO 3310-1, mesh sizes: $0.5 \mathrm{~mm}$, $0.71 \mathrm{~mm}, 0.85 \mathrm{~mm}, 1.00 \mathrm{~mm}, 1.18 \mathrm{~mm}, 1.40 \mathrm{~mm}, 1.70 \mathrm{~mm}$ and $2.00 \mathrm{~mm}$ ) for the samples Dalum $\mathrm{RW}$, Dalum $_{A F}$, Brøndbyvester, Sønders $\varnothing$, Lejre, Regnemark, Frederiksberg ${ }_{R W}$, sand, Havdrup, Frederiksberg ${ }_{A F}, A_{R}$,

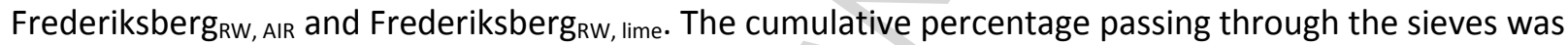
plotted against the sieve mesh size and the $10 \%$ fractile $\left(D_{10}\right)$, the median particle size $\left(D_{50}\right)$ and $60 \%$ fractile $\left(D_{60}\right)$ were read from the graphs. The uniformity coefficient (UC) was calculated as the ratio between $D_{60}$ and $D_{10}$. The specific surface area of pellets was quantified with the Brunauer-Emmett-Teller (BET) method using a Micrometric Gemini III 2375 Surface Area Analyzer. Dried sample (2 g) was degassed with nitrogen gas for at least 4 hours (FlowPrep 060) to remove air and excess humidity from the sample. The pellet mineralogy was determined with X-ray diffraction (XRD) using a Philips PW 1830 XRD Generator, a Philips PW 1050/25 monochromator, a Philips PW 1710 diffractometer and a Philips PW 2273/20 Cu-X-ray tube. The sample was powdered $(<50 \mu \mathrm{m})$ in an agate mortar, filled into a sample holder cavity and the diffractive pattern was measured with $\mathrm{Cu}$ Ka radiation scanning from $2^{\circ}$ to $65^{\circ} 2 \theta$ with a velocity of $0.1^{\circ} / 2 \mathrm{~s}$. The XRD patterns were interpreted by comparison to known patterns of calcite, aragonite, vaterite, manganoan calcite, magnesian calcite, dolomite and quartz. Pellets were withdrawn from 1, 3, 4, 5 and 5.7 $m$ depth at Dalum DWTP. The pellets were fitted in a resin and bisected. Images with Scanning Electron Microscopy (SEM, FEI QUANTA 200) were taken of the pellet bisects with backscatter electrons. The pellet 
reactivity was quantified by the Sauerbeck \& Rietz method using a pH-stat titration with $\mathrm{HCl}$ at $\mathrm{pH} 2.0$ for 10 min (Sauerbeck and Rietz, 1985) by the laboratory of the limestone supplier Faxe Kalk A/S.

\section{Results and discussion}

\subsection{Chemical composition of pellets during start-up of reactor}

During start-up of the pilot-scale pellet reactor at Sønders $\varnothing$ DWTP, the concentration of Ca in the pellets increased with increasing pellet size since the mass of the seeding material constituted decreasingly less of the total mass as the layer of precipitated $\mathrm{CaCO}_{3}$ increased. The concentrations of 8 elements were expressed as function of the Ca concentration showing their development with increasing pellet size as well as their development over time (Figure 2). The concentrations of the other elements were below the limit of quantification. The concentrations of $\mathrm{Na}, \mathrm{Mg}, \mathrm{Sr}, \mathrm{Fe}, \mathrm{P}, \mathrm{Mn}$ and $\mathrm{Zn}$ increased constantly with increasing Ca content, suggesting that these elements precipitated together with $\mathrm{CaCO}_{3}$ (Figure 2). On contrary, the Al concentration decreased with increasing Ca content indicating that Al was not incorporated into the crystal lattice of $\mathrm{CaCO}_{3}$ to the same degree as the other elements or that Al was present in the seeding material. After approximately 16 days of operation, pellets had reached their final diameter $\left(D_{50}=1.1 \mathrm{~mm}\right.$, Table 5$)$, and the concentrations of both $\mathrm{Ca}$ and foreign elements did not change further (Figure 2). Due to the development in concentration over time, the concentrations in pellets may be either under- or overestimated if pellets are sampled and analysed before reaching their final diameter. In practice, the rate of pellet growth, and thereby when the concentrations in pellets are constant, depends on e.g. the initial hardness and softening depth. Consequently, to represent the chemical composition during long-term operation, pellets should reach their final diameter before their chemical composition is analysed. Therefore, the chemical composition of pellets reported in the following is based on several samples collected after the pellets had their final diameter or the last withdrawn pellet sample. 


\subsection{Chemical composition of pellets at final pellet diameter}

Between the different locations and water qualities, the pellets appeared visually different in terms of particle size and colour, ranging from bright white to rusty red (Figure 3). The darkest pellets were from softening after aeration, whereas the brightest white pellets were from softening after rapid sand filtration. The chemical composition of pellets can determine the technical feasibility of reuse applications and the results should be compared to relevant guideline concentrations. However, the guideline concentrations vary depending on national legislation or which specific company or industry that may reuse the pellets.

In addition to a complete dissolution of the pellets, the chemical composition was analysed by only partially dissolving pellets to investigate if the composition of the outer part of the pellets, predominantly formed in the bottom of the reactor, vary from the overall composition. However, due to too few samples these investigations did not yield any clear conclusions (Supplementary material A).

\subsubsection{Pellet mass balance}

To verify that all relevant elements were included in the ICP-MS and ICP-OES analyses, a mass balance of the chemical composition of pellets was established for the samples 'Brokilde', 'Lejre', 'Havdrup' and 'Solhøj' (Figure 4). It was assumed that all Ca was precipitated as $\mathrm{CaCO}_{3}$ as reported in literature (van Dijk and Wilms, 1991) and the mass of the seeding material (quartz sand) was included. Other elements (e.g. Fe and $\mathrm{Mn}$ ) may have precipitated as carbonates $\left(\mathrm{FeCO}_{3}\right.$ or $\left.\mathrm{MnCO}_{3}\right)$ in the pellets, but since the concentrations of these elements were relatively low compared to $\mathrm{Ca}$, a conversion of their concentrations to precipitation products would have only limited effect on the overall mass balance.

The mass balance accounted for 98 to $104 \%$ of the total pellet mass indicating that all the major elements with a relevant contribution to the total pellet mass were quantified (Figure 4). The Ca concentrations were highest (319,000 - 442,000 mg/kg, Table 3), resulting in $\mathrm{CaCO}_{3}$ representing 88.3 to $100.0 \%$ of the total pellet mass. Sr, Mg, Fe and $\mathrm{Na}$ contributed with $0.0012-1.3 \%$ of the total pellet mass, whereas the sum of $\mathrm{Mn}, \mathrm{P}, \mathrm{K}, \mathrm{Zn}, \mathrm{Al}, \mathrm{Ni}, \mathrm{Cu}, \mathrm{Li}, \mathrm{Cr}, \mathrm{Sn}, \mathrm{Pb}, \mathrm{As}$ and $\mathrm{Cd}$ (grouped as 'others' in Figure 4) contributed to less than 
$0.04 \%$ of the total pellet mass. Nevertheless, these elements may still be relevant to include when analysing pellets, since metals such as $\mathrm{As}, \mathrm{Ni}$ and $\mathrm{Zn}$ can limit the reuse even at low concentrations due to their toxicity. The pellets furthermore contained the seeding material (quartz sand) which constituted up to $15 \%$ of the pellet mass (Figure 4). Replacing quartz sand as seeding material with $\mathrm{CaCO}_{3}$ from crushed pellets or quarry limestone increases the $\mathrm{CaCO}_{3}$ purity of pellets and the number of potential reuse applications for pellets within e.g. glass production (Aqua Minerals, 2016). The required $\mathrm{NaOH}$ dosage was not affected by substituting quartz sand with limestone at Frederiksberg DWTP, which is in agreement with literature (Schetters et al., 2015).

\subsubsection{Variations in chemical composition of pellets}

The concentrations of the elements varied among the pellet samples from different DWTPs (Table 3). The observed variation in Ca concentrations may be due to differences in pellet diameter and the relative mass of the seeding material. The Ca concentration was lowest $(319,000 \mathrm{mg} / \mathrm{kg})$ in pellets from Lindved DWTP, which also had the highest standard deviation $(52,000 \mathrm{mg} / \mathrm{kg})$. Even though the pilot-scale pellet reactor was operating for 44 days at Lindved DWTP, the large standard deviation on the Ca concentration indicates that the fluidized bed did not stabilize within this period, which may be because pellets were not completely fluidized (Section 2.1). Consequently, the particle size distribution was not analysed for these pellets, but they visually appeared to be relatively smaller compared to other samples (Figure 3).

The concentrations in pellets varied most for Fe and $\mathrm{Mn}$ (Table 3). Fe and $\mathrm{Mn}$ are oxidized during aeration and removed during rapid sand filtration in the DWTPs (de Moel et al., 2006), resulting in lower influent concentrations to the pellet reactor when pellet softening was conducted after rapid sand filtration than before aeration. At Dalum DWTP and Frederiksberg DWTP the pilot-scale reactor treated both raw groundwater and water after rapid sand filtration. The iron concentration in pellets was $2,200-8,700$ $\mathrm{mg} / \mathrm{kg}$ and manganese was $220-980 \mathrm{mg} / \mathrm{kg}$ when softening raw groundwater before aeration. Iron decreased to $26-100 \mathrm{mg} / \mathrm{kg}$ and manganese to $1.0-80 \mathrm{mg} / \mathrm{kg}$ when softening was after rapid sand filtration (Table 3). 
Concentrations of $\operatorname{Sr}(1,600-13,000 \mathrm{mg} / \mathrm{kg})$ and $\mathrm{Mg}(2,700-4,700 \mathrm{mg} / \mathrm{kg})$ were relatively high in the pellets from all DWTPs and varied only little with the placement of softening in the water treatment train (Table 3), since neither Sr nor Mg is removed by rapid sand filtration (O'Donnell et al., 2016). The concentrations of P, $\mathrm{K}, \mathrm{Zn}, \mathrm{Al}, \mathrm{Ni}, \mathrm{Cu}$ and Li were relatively low $(<200 \mathrm{mg} / \mathrm{kg})$ and were not influenced by the placement of softening in the treatment train, whereas $\mathrm{Cr}, \mathrm{Sn}, \mathrm{Pb}, \mathrm{As}, \mathrm{Tl}$ and $\mathrm{Cd}$ were below the quantification limit in the majority of the samples (Table 3).

\subsection{Chemical composition of pellets dependency on water chemistry}

If the chemical composition of pellets correlates with the influent water chemistry, it is possible to predict the concentration of an element in pellets based on the influent water concentration. It was not possible to test for a correlation for $\mathrm{Al}, \mathrm{Cu}, \mathrm{P}, \mathrm{Li}, \mathrm{Cr}, \mathrm{Sn}, \mathrm{Pb}, \mathrm{Tl}$ and $\mathrm{Cd}$ because either the concentrations were below the detection limit or the number of measurements was too low (Table 3, Supplementary material B). Na was added to the reactor from both the influent water and as $\mathrm{NaOH}$ in the softening process and was not considered in the analysis.

A D’Agostino-Pearson test confirmed that the pellet concentrations of $\mathrm{Mg}$ and $\mathrm{Sr}$ were normally distributed. Hence a Pearson's correlation coefficient $\left(R^{2}\right)$ between the concentration og $M g$ and $\mathrm{Sr}$ in the influent water and in the pellets was quantified and linear regression models were fitted to the data (Figure 5). For $\mathrm{Mg} \mathrm{R}^{2}$ was 0.339 , showing that the concentration of $\mathrm{Mg}$ in the pellets could not be described as a linear function of the influent water concentration. The removal of $\mathrm{Mg}$ from the water during pellet softening ranged from 0 to $12 \%$ of the influent water concentration, and $\mathrm{Mg}$ was hence only incorporated to a limited extent in the pellets compared to the other elements (Table 4). Mg is removed similarly in Dutch full-scale pellet reactors (Kiwa N.V., 2003). A linear regression model was fitted for $\mathrm{Sr}$ with $\mathrm{R}^{2}=0.812$ indicating that $81 \%$ of the variance in the pellet concentration can be described from the influent water concentration (Figure 5). The calculated slope was 2.25, meaning that $1 \mu \mathrm{g} \mathrm{Sr} / \mathrm{L}$ in the influent water results in $2.25 \mathrm{mg} \mathrm{Sr} / \mathrm{kg}$ in pellets. Consequently, it is possible to predict the concentration of $\mathrm{Sr}$ in pellets before pellet softening is implemented by analysing the influent water concentration of Sr. 
The correlations of Fe, Mn, Zn, K, As and Ni were tested with a Spearman's rank correlation coefficient, $r$. The concentrations of $\mathrm{Fe}, \mathrm{Mn}$ and $\mathrm{Ni}$ in the pellets correlated strongly with the influent water composition. The correlation between the water and pellet concentrations of Fe and $\mathrm{Mn}$ and the results from Section 3.2.2 show that by softening after rapid sand filtration, the concentrations of Fe and $\mathrm{Mn}$ in pellets can be reduced, which may result in improved possibilities for reuse.

For As and $\mathrm{K}$ the pellet concentrations did not correlate with the influent water concentration, and for $\mathrm{Zn}$ only a weak correlation was found. The removal of As during lime softening is reported to be greatly affected by pH (Choong et al., 2007); However, it was not possible to identify any trend for As in this study.

\subsection{Chemical speciation and precipitation with $\mathrm{CaCO}_{3}$}

The chemical speciation of elements in the water phase in the bottom and top of the pilot-scale reactor was modelled to investigate how the chemical speciation varied with the height of the reactor (Figure 1). The concentrations of different elements and $\mathrm{pH}$ are highest in the bottom of the reactor where influent water and $\mathrm{NaOH}$ enters the reactor, and $\mathrm{CaCO}_{3}$ has not precipitated yet; the lowest $\mathrm{pH}$ and concentrations are in the top of the reactor (de Moel et al., 2006). Due to the small reactor diameter $(9.9 \mathrm{~cm}), \mathrm{NaOH}$ was assumed to completely mix with the influent water. The chemical speciation of the elements was furthermore compared to their removal from the water to investigate if the chemical speciation can predict which elements precipitate as impurities in pellets. When $\mathrm{CaCO}_{3}$ precipitates it may precipitate with elements forming solid-solutions consisting of a mixture of minerals (Merkel and Planer-Friedrich, 2005). Consequently, elements must be available as carbonates for solid-solution formation with $\mathrm{CaCO}_{3}$ to occur.

The speciation modelling revealed that $\mathrm{K}$ and As did not form carbonates which is in agreement with the limited removal from the water ( 0 - $4 \%$, Table 4$)$, and with the fact that $K$ and As in pellets did not correlate with the influent water concentrations (Section 3.3). The chemical speciation of the other elements varied with the height of the reactor. $\mathrm{Pb}, \mathrm{Ni}$, and $\mathrm{Zn}$ had a higher tendency of carbonate formation in the top of the reactor compared to the bottom. Conversely, $\mathrm{Ca}, \mathrm{Mg}$, $\mathrm{Fe}, \mathrm{Cu}$ and $\mathrm{Sr}$ primarily formed carbonates in the 
bottom of the reactor, indicating more precipitation in the bottom of the reactor, at higher $\mathrm{pH}$. This is in line with findings in Hammes et al. (2011). Ni, Fe, Mn, Mg and Sr had a strong correlation between the influent water composition and the concentration in pellets (Section 3.3), but a difference in where in the pellet reactor the tendency for carbonate formation was highest. This indicates that the removal of these elements in the pellet reactor occurs at different $\mathrm{pH}$ conditions over the height of the reactor.

There was no observed trend between a high degree of carbonate formation and a high removal of specific elements from the water. For instance, $\mathrm{CaCO}_{3}$ constituted $39 \%$ of $\mathrm{Ca}$ in the bottom of the reactor and was removed by $81 \%$, whereas $\mathrm{FeCO}_{3}$ accounted for $86 \%$ of $\mathrm{Fe}$ and was removed by $83 \%$. Likewise, $\mathrm{Mg}$ was present as $\mathrm{MgCO}_{3}$, but was only removed by $0-12 \%$. The PHREEQC model used in this study only included pure minerals and hence neglected the effects from solid-solution formation. Furthermore, the PHREEQC model did not include sorption processes and kinetics, which may also affect the removal of elements from the water (Merkel and Planer-Friedrich, 2005). Consequently, the chemical speciation modelling could predict which elements form carbonates and can potentially be incorporated into pellets, whereas the removal of elements was more complex and should be accessed based on chemical analyses of pellets or with more advanced water quality modelling.

\subsection{Reactivity, mineralogy and specific surface area}

\subsubsection{Reactivity and specific surface area}

The pellet reactivity is important for pellets to be reused for soil amendment in agriculture. The pellet reactivity is related to the specific surface area and pellet size (Kiil et al., 1999), which were also quantified. The pellet reactivity was 7.39 - $25.7 \%$ (Table 5), which is low compared to commercial calcite products for agricultural soil amendment where the reactivity often exceeds $70 \%$ in Denmark (DLG, 2010). The reactivity of the 4 Dutch pellet samples from full-scale pellet softening was $9.60-22.1 \%$. Therefore, the results from the pilot-scale investigations were in line with full-scale pellet softening with other operating 
conditions than the investigated including surface water treatment, $\mathrm{Ca}\left(\mathrm{OH}_{22}\right.$ as chemical base and garnet sand as seeding material.

The pellet median diameter $\left(D_{50}\right)$ was $0.88-1.60 \mathrm{~mm}$ and the uniformity coefficient (UC) was $1.09-1.94$ indicating that pellets were uniform in size. The pellet diameters were within the range observed in e.g Dutch full-scale pellet reactors (0.8 - $1.2 \mathrm{~mm}$ ) (Kiwa N.V., 2003), except the samples from Brøndbyvester $(1.60 \mathrm{~mm})$, Regnemark $(1.32 \mathrm{~mm})$ and Havdrup $(1.25 \mathrm{~mm})$. The specific surface area of the pellets was measured to be $0.0010-0.32 \mathrm{~m}^{2} / \mathrm{g}$ (Table 5), however, since the quantification limit was $1.43 \mathrm{~m}^{2} / \mathrm{g}$ for calcite and $0.33 \mathrm{~m}^{2} / \mathrm{g}$ for quartz, these results were uncertain. Consequently, it was not possible to investigate the correlation between specific surface area, reactivity and pellet diameter. Nonetheless, the specific surface areas below the quantification limit indicate that the pellets have a low porosity. Materials with a low specific surface area have fewer sites for reaction thereby decreasing the reactivity (Kiil et al., 1999), which may explain the low reactivity compared to commercial limestone products. The low reactivity and specific surface area of pellets may be a limitation for reuse as soil amendment in agriculture; although, this is currently being investigated further in the Netherlands (Aqua Minerals, 2015).

\subsubsection{Mineralogy}

The polymorph form of pellets was investigated by the pellet mineralogy, since this affects the physical characteristics of pellets and hence reuse potentials. All pellets crystallized as calcite during the pilot-scale experiments despite different influent water quality and seeding material (Table 5). Thus, the conversion of $\mathrm{Ca}$ to $\mathrm{CaCO}_{3}$ in the mass balance was valid (Section 3.2.1) and similar to findings in literature (Hammes et al., 2011). In addition to calcite, quartz was detected in all pellets with a quartz sand seeding material. The 4 samples from full-scale pellet reactors also consisted of calcite indicating that the results were representative of full-scale pellet softening (Table 5). The SEM images of pellet bisects show that the calcite layer on the seeding material increased with increasing reactor depth (Figure 6), which reflects the expected stratification of pellets (van Schagen et al., 2008b). A weak signal from quartz was detected in the 
samples Frederiksberg ${ }_{A F, A I R}$ and Frederiksberg ${ }_{R W, A I R}$, which may be from impurities in the limestone seeding material. The limestone seeding material did not affect the mineralogy of the precipitated $\mathrm{CaCO}_{3}$, but did increase the pellet purity by avoiding the quartz sand impurity.

$\mathrm{Fe}^{2+}$ concentrations exceeding $4 \mathrm{mg} / \mathrm{L}$ and phosphate concentrations exceeding $1 \mathrm{mg} / \mathrm{L}$ can interfere with the crystallization resulting in porous, 'fluffy' pellets (Ruhland and Jekel, 2004; van Dijk and Wilms, 1991). At the investigated DTWPs the Fe concentrations were below $4 \mathrm{mg} / \mathrm{L}$, with $3.8 \mathrm{mg} / \mathrm{L}$ as the highest concentration (Frederiksberg DWTP). The phosphate concentrations were less than $0.1 \mathrm{mg} / \mathrm{L}$, and as expected no porous pellets were formed. Hammes et al. (2011) reported a more porous crystalline structure in the inner part of the pellets indicating that the crystallization in the upper part of the reactor varied from the lower part. This was explained by bacteria colonization in the upper part of the reactor where $\mathrm{pH}$ is more favourable for microbial growth. Such difference in mineralogy was not observed in this study (Figure 6), which may be explained by the experimental setup e.g. water was treated by ozonation prior to pellet softening promoting bacteriological growth in the study of Hammes et al. (2011).

In contrast to the chemical composition of pellets, the mineralogy of pellets did not vary between the DWTPs within the range of investigated influent water composition and seeding materials. Precipitation into aragonite instead of calcite could result in a higher sales value of pellets and can be promoted by e.g. addition of magnesium and organic additives (Park et al., 2008). However, this was beyond the scope of the present study since it may not be suitable for drinking water production.

\section{Practical implications}

Pellet characteristics affect the technical feasibility of the pellet reuse applications. However, from an economic and environmental point of view, the choice of reuse application also depends on e.g. the pellet sales value, which material the pellets substitute, transportation distances and the further processing of pellets. These aspects should be taken into account when designing pellet reuse. 
Modifying the design of the pellet softening process and where it is applied in the water treatment train would not only affect pellet characteristics, but also the overall water treatment process. As a result, optimizing the quality of pellets may compromise the overall feasibility of the water treatment process. Softening before aeration results in higher concentrations of Fe and $\mathrm{Mn}$ in pellets compared to after rapid sand filtration, which can be a disadvantage for pellet reuse; however, the removal of Fe and $\mathrm{Mn}$ from the water reduces the loads on the following rapid sand filtration, which can be favourable from an operational point of view (van Dijk and Wilms, 1991). In the same way, the placement of pellet softening after rapid sand filtration is favourable from a pellet reuse point of view since the pellets contain less impurities, but requires an additional filtration step to remove potential $\mathrm{CaCO}_{3}$ carry-over from the softening process (van Dijk and Wilms, 1991). In addition, several of the elements analysed in this study, e.g. As and $\mathrm{Ni}$, have toxic effects and are regulated in drinking water legislation (de Moel et al., 2006). It may be beneficial from a water quality perspective to remove these elements from the water by incorporation into pellets, even though that may limit the possibilities for pellet reuse.

Due to the complexity in the examples given above, the optimal design of the pellet softening process may vary, depending on e.g. the abstracted water quality and the existing water treatment process. Therefore many different process designs are observed for full-scale pellet softening (Kiwa N.V., 2003). Including pellet reuse in the design phase of the softening process may promote a more cost-effective and environmentally sustainable design of the overall water treatment process.

\section{Conclusions}

The characteristics of $\mathrm{CaCO}_{3}$ pellets from pilot-scale pellet softening were investigated at 8 Danish DWTPs. The chemical composition of pellets varied with both the influent water quality and the investigated quartz sand and limestone seeding materials, and it was concluded that:

- Ca was the most abundant element in pellets comprising up to $100 \%$ of the pellet mass as $\mathrm{CaCO}_{3}$. In addition, a number of elements precipitated together with $\mathrm{CaCO}_{3}$ as impurities affecting the 
reuse potentials of the pellets. Especially $\mathrm{Sr}, \mathrm{Mg}$, Fe and $\mathrm{Na}$ contributed most and each constituted 0.0012 to $1.3 \%$ of the pellet mass. The sum of the remaining elements contributed to less than $0.04 \%$ of the pellet mass. The pellets also consisted of the seeding material accounting for $1-15 \%$ of the pellet mass depending on the pellet size. Replacing quartz sand seeding material with limestone increases the pellet purity.

- The Fe concentration in pellets was $26-9,200 \mathrm{mg} / \mathrm{kg}$ and the $\mathrm{Mn}$ concentration was 0.5 - 980 $\mathrm{mg} / \mathrm{kg}$. Softening after rapid sand filtration resulted in the lowest concentrations of Fe and $\mathrm{Mn}$ hence increasing the pellet purity. The concentrations of $\mathrm{Fe}, \mathrm{Mn}, \mathrm{Mg}$, $\mathrm{Sr}$ and $\mathrm{Ni}$ in the pellets correlated strongly with the influent water concentrations. Sr can furthermore be predicted in pellets from the influent water concentration using a linear regression model. The concentrations of $\mathrm{K}$, As and $\mathrm{Zn}$ had no or only a weak correlation with the influent water chemistry.

- The precipitation of elements with $\mathrm{CaCO}_{3}$ was associated with great complexity. Modelling the chemical speciation showed that $\mathrm{K}$ and As did not form carbonates and consequently did not precipitate with $\mathrm{CaCO}_{3}$. Other elements forming carbonates were incorporated into $\mathrm{CaCO}_{3}$ to varying degrees with removals from water ranging from 7 to $83 \%$.

- All pellets crystallised as calcite with a relatively low reactivity of $7.39-25.7 \%$ and a specific surface area of $<\mathrm{DL}-0.32 \mathrm{~m}^{2} / \mathrm{g}$. The reactivity and specific surface area did not vary with influent water composition and the investigated seeding material, and were in line with full-scale pellet softening in the Netherlands.

The pellet purity, and thereby reuse potentials, can be improved when designing the softening process. This can be achieved by reducing the concentrations of elements that precipitate as impurities in the pellets prior to pellet softening and using a limestone seeding material. This can allow for optimization with respect to both water quality and reuse of pellets, ultimately increasing the sustainability and economic feasibility of the softening process. 


\section{Acknowledgements}

This work was supported by the VTU Foundation and the Danish Ministry of Environment. The authors wish to thank the participating utility companies: VandCenter Syd, Frederiksberg Forsyning and HOFOR. We also thank Sune Thyge Ryssel and Sille Lyster Larsen for their contributions to data processing and interpretation as well as Sinh Nguyen for laboratory analyses and interpretation of XRD results. Finally, we thank Aqua Minerals for supplying pellet samples from full-scale reactors in the Netherlands and Faxe Kalk for performing reactivity analyses of pellets.

\section{Appendix A. Supplementary material}




\section{References}

Aqua Minerals, 2016. Annual Report 2016 [WWW Document]. URL http://aquaminerals.com/wpcontent/uploads/2017/04/Jaarbericht_AquaMinerals_16_EN_web-1.pdf (accessed 12.12.17).

Aqua Minerals, 2015. Annual Report 2015 [WWW Document]. URL http://aquaminerals.com/wpcontent/uploads/2017/04/Jaarbericht_AquaMinerals_15_EN_new.pdf (accessed 11.5.17).

Choong, T.S.Y., Chuah, T.G., Robiah, Y., Gregory Koay, F.L., Azni, I., 2007. Arsenic toxicity, health hazards and removal techniques from water: an overview. Desalination 217, 139-166. https://doi.org/10.1016/j.desal.2007.01.015

de Moel, P.J., Verberk, J.Q.J.C., van Dijk, J.C., 2006. Drinking Water. Principles and Practices, 1st ed. World Scientific Publishing Co. Pte. Ltd., Singapore.

DLG, 2010. Agricultural lime from Dankalk ensure optimal plant growth (Jordbrugskalk fra Dankalk sikrer optimal plantevækst) [WWW Document]. URL https://www.dlg.dk/Marken/Marken/Jordbrugskalk (accessed 8.20.17).

Godskesen, B., Hauschild, M., Rygaard, M., Zambrano, K., Albrechtsen, H.-J., 2012. Life cycle assessment of central softening of very hard drinking water. J. Environ. Manage. 105, 83-89. https://doi.org/10.1016/j.jenvman.2012.03.030

Hammes, F., Boon, N., Vital, M., Ross, P., Magic-knezev, A., Dignum, M., 2011. Bacterial colonization of pellet softening reactors used during drinking water treatment. Appl. Environ. Microbiol. 77, 10411048. https://doi.org/10.1128/AEM.02068-10

HOFOR, 2017. Less lime in the water (Mindre kalk i vandet) [WWW Document]. URL http://www.hofor.dk/vand/mindre-kalk-i-vandet/ (accessed 12.12.17).

Kiil, S., Johnsson, J.E., Dam-Johansen, K., 1999. Modelling of limestone dissolution in wet FGD systems: the importance of an accurate particle size distribution. Powerpl. Chem. 1, 26-30.

Kiwa N.V., 2003. Overview of pellet reactors in the Netherlands (Overzicht van de korrelreactoren in Nederland).

Larsen, S.L., Hedegaard, M.J., Lopato, L., Nielsen, O.D., Juul, H., Albrechtsen, H.-J., 2016. Demonstrationscale softening of drinking water (Demonstrationsanlæg til blødgøring af drikkevand: Fyrtårnsprojekt "Fremtidens Drikkevandsforsyning"). Danish Environmental Protection Agency, Copenhagen.

Marques, R.C., da Cruz, N.F., Pires, J., 2015. Measuring the sustainability of urban water services. Environ. Sci. Policy 54, 142-151. https://doi.org/10.1016/j.envsci.2015.07.003

Merkel, B.J., Planer-Friedrich, B., 2005. Groundwater geochemistry: a practical guide to modeling of natural and contaminated aquatic systems, 1st ed, Journal of Chemical Information and Modeling. Springer, Heidelberg. https://doi.org/10.1017/CBO9781107415324.004

Mudhoo, A., Garg, V.K., Wang, S., 2012. Heavy Metals: Toxicity and Removal by Biosorption, in: Environmental Chemistry for a Sustainable World. Springer Netherlands, pp. 379-442.

O’Donnell, A.J., Lytle, D.A., Harmon, S., Vu, K., Chait, H., Dionysiou, D.D., 2016. Removal of strontium from drinking water by conventional treatment and lime softening in bench-scale studies. Water Res. 103, 
319-333. https://doi.org/10.1016/j.watres.2016.06.036

Oates, J., 1998. Lime and Limestone: Chemistry and Technology, Production and Uses, 1st ed. Wiley-VCH, Weinheim.

Park, W.K., Ko, S., Woo, S., Cho, K., Ahn, J., Han, C., 2008. Effects of magnesium chloride and organic additives on the synthesis of aragonite precipitated calcium carbonate. J. Cryst. Growth 310, 25932601. https://doi.org/10.1016/j.jcrysgro.2008.01.023

Parkhurst, D.L., Appelo, C.A.J., 2013. Description of Input and Examples for PHREEQC Version 3 - A Computer Program for Speciation , Batch-Reaction, One-Dimensional Transport, and Inverse Geochemical Calculations, in: Modeling Techniques. U.S. Geological Survey, p. 497. https://doi.org/10.1016/0029-6554(94)90020-5

Ruhland, A., Jekel, M., 2004. Aspects in the choice of technology for centralised softening of drinking water - Part 1: Requirements and target quantities (Aspekte bei der Wahl von Verfahren der Zentralen Trinkwasserenthärtung - Teil 1: Voraussetzungen und Zielgrössen). Wasser - Abwasser 145, 98-111.

Sauerbeck, D., Rietz, E., 1985. A method for determining the reactivity of carbonate fertilizer lime (Ein Verfahren zur Bestimmung der Reaktionsfähigkeit kohlensauer Düngekalk). Landwirtsch. Forsch. Sonderh. 41, 682-690.

Schetters, M.J.A., Van Der Hoek, J.P., Kramer, O.J.I., Kors, L.J., Palmen, L.J., Hofs, B., Koppers, H., 2015. Circular economy in drinking water treatment: reuse of ground pellets as seeding material in the pellet softening process. Water Sci. Technol. 71, 479-486. https://doi.org/10.2166/wst.2014.494

Sydvatten, 2016. Sydvatten - collaborating for public welfare [WWW Document]. URL http://sydvatten.se/wp-content/uploads/2016/02/Sydvatten-in-English.pdf (accessed 11.5.17).

US EPA, 2007. Method 3051A Microwave assisted acid digestion of sediments, sludges, soils and oils 1-30.

van der Bruggen, B., Goossens, H., Everard, P.A., Stemgée, K., Rogge, W., 2009. Cost-benefit analysis of central softening for production of drinking water. J. Environ. Manage. 91, 541-549. https://doi.org/10.1016/j.jenvman.2009.09.024

van Dijk, J.C., Wilms, D.A., 1991. Water treatment without waste material - fundementals and state of the art of pellet softening. J. Water Supply Res. Technol. - Aqua 40, 263-280.

van Eekeren, M.W.M., van Paassen, J.A.M., Merks, C.W.A.M., 1994. Improved milk-of-lime for softening of drinking water - the answer to the carry-over problem. J. Water SRT - Aqua 43, 1-11.

van Schagen, K.M., Rietveld, L., Babuška, R., Baars, E., 2008a. Control of the fluidised bed in the pellet softening process. Chem. Eng. Sci. 63, 1390-1400. https://doi.org/10.1016/j.ces.2007.07.027

van Schagen, K.M., Rietveld, L.C., Babuska, R., Kramer, O.J.I., 2008b. Model-based operational constraints for fluidised bed crystallisation. Water Res. 42, 327-337.

https://doi.org/10.1016/j.watres.2007.07.019

Waly, T., Kennedy, M.D., Witkamp, G., Amy, G., Schippers, J.C., 2012. The role of inorganic ions in the calcium carbonate scaling of seawater reverse osmosis systems. Desalination 284, 279-287. https://doi.org/10.1016/j.desal.2011.09.012

World Health Organization, 2011. Hardness in Drinking-water: Background Document for Development of 
WHO Guidelines for Drinking-water Quality, World Health Organization. Geneva. https://doi.org/WHO/HSE/WSH/10.01/10/Rev/1 


\section{Tables}

Table 1: Pellets samples and the operating conditions for each pilot-scale investigation. AF: After filtration, RW: Raw water, AIR: After air stripper. Quartz: With quartz sand seeding material. Lime: With limestone seeding material.

\begin{tabular}{|c|c|c|c|c|c|c|c|}
\hline \multirow[t]{2}{*}{ DWTP } & \multirow{2}{*}{$\begin{array}{l}\text { Water type } \\
\text { Sample ID }\end{array}$} & \multirow{2}{*}{$\begin{array}{c}\text { Duration of } \\
\text { experiment } \\
\text { [d] }\end{array}$} & \multicolumn{3}{|c|}{$\begin{array}{c}\text { Implementation in treatment } \\
\text { train }\end{array}$} & \multicolumn{2}{|c|}{ Seeding material } \\
\hline & & & $\begin{array}{l}\text { Before } \\
\text { aeration }\end{array}$ & $\begin{array}{c}\text { After } \\
\text { aeration }\end{array}$ & $\begin{array}{c}\text { After } \\
\text { filtration }\end{array}$ & Quartz & Limestone \\
\hline \multirow[t]{2}{*}{ Marbjerg } & Marbjerg & $451^{a}$ & $x$ & - & - & $x$ & - \\
\hline & Brokilde & $451^{a}$ & $x$ & - & - & $x$ & - \\
\hline \multirow[t]{3}{*}{ Brøndbyvester } & Brøndbyvester & 16 & $x$ & - & - & $x$ & - \\
\hline & Brøndbyvester $_{\mathrm{AF}}$ & 4 & - & - & $x$ & $x$ & - \\
\hline & Regnemark & 14 & - & - & $x$ & $x$ & - \\
\hline Sønders $\varnothing$ & Sønders $\varnothing$ & 27 & $x$ & - & - & $x$ & - \\
\hline Lejre & Lejre & 32 & $x$ & - & - & $X$ & - \\
\hline \multirow[t]{2}{*}{ Thorsbro } & Solh $\varnothing j$ & 23 & - & - & $(X)^{b}$ & $X$ & - \\
\hline & Havdrup & 29 & $x$ & - & - & $x$ & - \\
\hline \multirow[t]{2}{*}{ Dalum } & Dalum $_{\mathrm{RW}}$ & 65 & $x$ & - & - & $x$ & - \\
\hline & Dalum $_{\mathrm{AF}}$ & 24 & - & - & $x$ & $x$ & - \\
\hline Lindved & Lindved & 44 & - & $(X)^{c}$ & - & $x$ & - \\
\hline \multirow[t]{4}{*}{ Frederiksberg } & Frederiksberg ${ }_{\mathrm{RW}, \text { sand }}$ & 21 & $x$ & - & - & $x$ & - \\
\hline & Frederiksberg ${ }_{R W, l i m e}$ & 6 & $x$ & - & - & - & $x$ \\
\hline & Frederiksberg ${ }_{A F, A I R}$ & 10 & - & - & $X$ & - & $x$ \\
\hline & Frederiksberg ${ }_{\mathrm{RW}, \mathrm{AIR}}$ & 6 & - & $x$ & - & - & $x$ \\
\hline
\end{tabular}

\footnotetext{
${ }^{\text {a }}$ During the time period both water from Marbjerg and Brokilde were treated. The pilot-scale reactor did not operate for the entire time period.

${ }^{b}$ Water quality from the Solhøj well field after air stripping resembles the water quality after filtration

${ }^{c}$ The raw water was partially aerated before pellet softening
} 
Table 2: Pellet samples from full-scale softening at Dutch DWTPs included in the study, which are produced from different water types and with different operating conditions of the softening process.

\begin{tabular}{llcll}
\hline DWTP & Water source & Softening chemical & Implementation in & Seeding material \\
Sample ID & & & treatment train \\
\hline Seppe & Groundwater & $\mathrm{Ca}(\mathrm{OH})_{2}$ & After aeration & Limestone \\
Weesperkarspel & Surface water & $\mathrm{NaOH}$ & After filtration & Limestone \\
de Beitel & Groundwater & $\mathrm{NaOH}$ & After aeration & Garnet sand \\
Hoogeveen & Groundwater & $\mathrm{Ca}(\mathrm{OH})_{2}$ & After pre-filtration & Quartz sand \\
\hline
\end{tabular}


Table 3: Chemical composition of pellets from Danish pilot scale investigations including number of samples, mean and standard deviation (SD). NM indicates not measured. - indicates not relevant (only a single measurement or all below limit of detection). $n$ indicates the number of samples. If $n$ is not stated, the analysis is from a single sample. All concentrations are in $\mathrm{mg} / \mathrm{kg}$.

\begin{tabular}{|c|c|c|c|c|c|c|c|c|c|c|c|c|c|c|c|c|c|c|c|c|}
\hline & & $\mathrm{Ca}$ & $\mathrm{Sr}$ & Mg & $\mathrm{Fe}$ & $\mathrm{Na}$ & $\mathrm{Mn}$ & $\mathbf{P}$ & K & $\mathrm{Zn}$ & Al & $\mathrm{Ni}$ & $\mathrm{Cu}$ & $\mathrm{Li}$ & $\mathrm{Cr}$ & Sn & $\mathrm{Pb}$ & As & TI & $\mathrm{Cd}$ \\
\hline Marbjerg & Mean & 373,000 & 4,400 & 4,600 & 1,300 & 1,500 & 93 & 91 & 100 & 17 & 28 & 5.1 & 1.2 & NM & 0.4 & $<0,03$ & $<0,02$ & $<0.1$ & 0.04 & 0.1 \\
\hline$n=5$ & SD & 9,300 & 120 & 450 & 130 & 100 & 6 & 6 & 11 & 1.1 & 11 & 0.6 & 1.2 & - & 0.2 & - & - & - & 0.06 & 0.0 \\
\hline Brokilde & - & 353,000 & 4,700 & 3,700 & 5,400 & 1,000 & 93 & 55 & 34 & 20 & 29 & 3.1 & $<0.8$ & 0.8 & $<0.05$ & NM & $<0.1$ & $<0.4$ & $<1.0$ & $<0.1$ \\
\hline Brøndby & Mean & 378,000 & 4,100 & 4,200 & 3,900 & 1,700 & 84 & 180 & 100 & 63 & $<0.7$ & 36 & 0.54 & NM & $<0.29$ & 0.2 & 0.7 & $<0.51$ & $<0.044$ & $<0.21$ \\
\hline$n=4$ & SD & 15,000 & 59 & 270 & 100 & 150 & 4 & 40 & 5 & 8 & - & 2 & 0.01 & & - & 0.1 & 0.5 & - & - & \\
\hline Brøndbyvester ${ }_{A F}$ & - & 403,000 & 6,900 & 4,700 & 19 & 1,600 & 3.1 & 150 & 100 & 130 & $<0.7$ & 14 & $<0.36$ & - & $<0.29$ & 0.2 & 0.4 & $<0.51$ & 0.1 & $<0.21$ \\
\hline Regnemark & Mean & 393,000 & 8,200 & 4,000 & 24 & 1,300 & 0.5 & 120 & $<94$ & 110 & $<0.1$ & 0.9 & 0.4 & NM & $<0.29$ & 1.1 & 1.4 & $<0.51$ & $<0.044$ & $<0.21$ \\
\hline$n=4$ & SD & 10,500 & 240 & 200 & 11 & 130 & 0.2 & 1.0 & - & 14 & & 0.6 & 0.3 & NM & - & 1.7 & 1.8 & - & - & - \\
\hline Sønders $\varnothing$ & Mean & 395,000 & 3,900 & 2,700 & 9,200 & 1,400 & 280 & 130 & 150 & 14 & 22 & 0.5 & $<0.28$ & NM & $<0.15$ & $<0.16$ & $<0.18$ & $<0.19$ & $<0.04$ & $<0.06$ \\
\hline$n=7$ & SD & 11,600 & 130 & 60 & 310 & 130 & 12 & 6 & 140 & 2.2 & & 0.4 & - & NM & - & - & & - & - & \\
\hline Lejre & - & 400,000 & 13,000 & 3,900 & 3,900 & 1,400 & 240 & 64 & 30 & 3.5 & $<24$ & 2.8 & 1.2 & 1.9 & 0 & NM & $<0.1$ & $<0.4$ & $<1.0$ & $<0.1$ \\
\hline Solhøj & - & 383,000 & 1,900 & 3,500 & 12 & 1,200 & 0.5 & 19 & 31 & 92 & $<24$ & 15 & 12 & 0.6 & $<0.05$ & NM & 0.3 & $<0.4$ & $<1.0$ & $<0.1$ \\
\hline Havdrup & - & 384,000 & 6,200 & 4,600 & 650 & 1,400 & 98 & 14 & 36 & 22 & $<24$ & 6.2 & $<0.8$ & 1.0 & 0.3 & NM & $<0.1$ & $<0.4$ & $<1.0$ & $<0.1$ \\
\hline Dalum $_{\mathrm{RW}}$ & Mean & 395,000 & 1,600 & 3,600 & 2,200 & 1,600 & 980 & 160 & 100 & $<3.4$ & 28 & 3.7 & 0.3 & 1.6 & 1.2 & $<0.18$ & 0.1 & 0.1 & $<0.21$ & $<0,01$ \\
\hline$n=3$ & SD & 7,800 & 47 & 100 & 38 & 27 & 20 & 9 & 12 & - & 6 & 0.1 & 0.0 & 0.1 & 0.0 & - & 0.0 & 0.0 & - & - \\
\hline Dalum $_{\mathrm{AF}}$ & Mean & 394,000 & 1,600 & 3,600 & 26 & 1,400 & 1.0 & $<55$ & 130 & 30 & 20 & 4.3 & 4.6 & 1.4 & 1.3 & $<0.18$ & 0.2 & 0.3 & $<0.21$ & 0.01 \\
\hline$n=4$ & SD & 11,000 & 42 & 76 & 3 & 100 & 0.1 & - & 4 & 2 & 3 & 0.2 & 2.1 & 0.0 & 0.1 & - & 0.0 & 0.0 & - & 0.0 \\
\hline Lindved & Mean & 319,000 & 2,800 & 3,400 & 1,600 & 900 & 530 & 60 & $<74$ & 16 & 34 & 2.8 & 0.6 & 1.3 & $<0.99$ & $<0.18$ & 0.2 & 1.1 & $<0.21$ & 0.02 \\
\hline$n=4$ & SD & 52,000 & 470 & 280 & 120 & 49 & 100 & 4 & - & 3 & 17 & 0.4 & 0.2 & 0.1 & - & - & 0.0 & 0.1 & - & 0.01 \\
\hline Frederiksberg ${ }_{\mathrm{RW}, \text { sand }}$ & - & 378,000 & 7,000 & 3,800 & 8,700 & 1,700 & 220 & 87 & 35 & 80 & 14 & 10 & 0.2 & NM & 0.4 & NM & 0.1 & 0.2 & 0.1 & 0.03 \\
\hline Frederiksberg ${ }_{\mathrm{RW}, \text { lime }}$ & - & 390,000 & 6,300 & 3,900 & 7,800 & 1,500 & 240 & 71 & 46 & 82 & 21 & 10 & 0.3 & NM & 0.3 & NM & 0.8 & 0.2 & 0.2 & 0.1 \\
\hline Frederiksberg AF,AlR & - & 428,000 & 4,800 & 3,600 & 100 & 1,100 & 80 & 56 & 62 & 130 & 21 & 12 & 0.6 & NM & 0.1 & NM & 0.7 & 0.3 & 0.1 & 0.1 \\
\hline Frederiksberg ${ }_{\mathrm{RW}, \mathrm{AIR}}$ & - & 442,000 & 5,200 & 4,100 & 1,900 & 1,200 & 210 & 70 & 53 & 59 & 22 & 12 & 0.2 & NM & 0.3 & NM & 0.6 & 1.0 & 0.1 & 0.04 \\
\hline
\end{tabular}


Table 4: Chemical speciation of elements (main species) in the bottom of the reactor $(\mathrm{pH}=9.8)$ and in the top of the reactor $(\mathrm{pH}=8.9)$. The removal of elements from water at Dalum DWTP is included together with the range of removals from all DWTPs in brackets. Carbonates are highlighted in bold.

\begin{tabular}{|c|c|c|c|c|}
\hline \multirow[t]{2}{*}{ Element } & Speciation [\%] & \multicolumn{2}{|c|}{ Speciation [\%] } & \multirow{2}{*}{$\begin{array}{c}\text { Removal from water } \\
{[\%]}\end{array}$} \\
\hline & Bottom of reactor & top of reac & & \\
\hline \multirow[t]{2}{*}{$\mathrm{Ca}$} & $\mathrm{Ca}^{2+}$ & $\mathrm{Ca}^{2+}$ & 92 & $81(78-87)$ \\
\hline & $\mathrm{CaCO}_{3}$ & $\mathrm{CaCO}_{3}$ & 6 & \\
\hline \multirow[t]{2}{*}{$\mathrm{Mg}$} & $\mathrm{Mg}^{2+}$ & $\mathrm{Mg}^{2+}$ & 95 & $70-12)$ \\
\hline & $\mathrm{MgCO}_{3}$ & $\mathrm{MgCO}_{3}$ & 3 & \\
\hline \multirow[t]{3}{*}{$\mathrm{Fe}$} & $\mathrm{FeCO}_{3}$ & $\mathrm{FeCO}_{3}$ & 47 & $83(28-96)$ \\
\hline & $\mathrm{Fe}^{2+}$ & $\mathrm{Fe}^{2+}$ & 42 & \\
\hline & $\mathrm{FeOH}^{+}$ & $\mathrm{FeHCO}_{3}{ }^{+}$ & & \\
\hline K & 100 & $\mathrm{~K}^{+}$ & 100 & $4(0-4)$ \\
\hline \multirow[t]{2}{*}{$\mathrm{Sr}$} & $\mathrm{Sr}^{2+}$ & $\mathrm{Sr}^{2+}$ & 96 & $61(59-67)$ \\
\hline & $\mathrm{SrCO}_{3}$ & $\mathrm{SrCO}_{3}$ & 2 & \\
\hline \multirow[t]{3}{*}{$\mathrm{Zn}$} & $\mathrm{Zn}\left(\mathrm{CO}_{3}\right)_{2}^{2-}$ & $\mathrm{Zn}\left(\mathrm{CO}_{3}\right)_{2}^{2-}$ & 52 & $48(48-93)$ \\
\hline & $\mathrm{Zn}(\mathrm{OH})$ & $\mathrm{ZnCO}_{3}$ & 27 & \\
\hline & $\mathrm{ZnCO}_{3}$ & $\mathrm{Zn}(\mathrm{OH})_{2}$ & 17 & \\
\hline \multirow[t]{2}{*}{$\mathrm{Ni}$} & $\mathrm{Ni}(\mathrm{CO} 3)_{2}^{2-}$ & $\mathrm{NiCO}_{3}$ & 86 & $49(3-79)$ \\
\hline & $\mathrm{NiCO}_{3}$ & $\mathrm{Ni}\left(\mathrm{CO}_{3}\right)_{2}^{2-}$ & 14 & \\
\hline \multirow[t]{3}{*}{$\mathrm{Cu}$} & $\mathrm{CuCO}_{3}$ & $\mathrm{Cu}(\mathrm{OH})_{2}$ & 97 & $0(0-74)$ \\
\hline & $\mathrm{Cu}(\mathrm{OH})_{2}$ & $\mathrm{CuCO}_{3}$ & 3 & \\
\hline & $\mathrm{CuHCO}_{3}{ }^{+}$ & & & \\
\hline \multirow[t]{3}{*}{$\mathrm{Pb}$} & $\mathrm{Pb}\left(\mathrm{CO}_{3}\right)_{2}^{2-}$ & $\mathrm{PbCO}_{3}$ & 80 & $16(0-71)$ \\
\hline & $\mathrm{PbCO}_{3}$ & $\mathrm{~Pb}\left(\mathrm{CO}_{3}\right)_{2}^{2-}$ & 18 & \\
\hline & $\mathrm{Pb}(\mathrm{OH})_{2}$ & & & \\
\hline \multirow[t]{2}{*}{ As } & $\mathrm{H}_{2} \mathrm{AsO}_{3}^{-}$ & $\mathrm{H}_{3} \mathrm{AsO}_{3}$ & 73 & $0(0)$ \\
\hline & $\mathrm{H}_{3} \mathrm{AsO}_{3}$ & $\mathrm{H}_{2} \mathrm{AsO}_{3}^{-}$ & 27 & \\
\hline
\end{tabular}


Table 5: Reactivity, median particle size ( $\left.D_{50}\right)$, uniformity coefficient, specific surface area \pm standard deviation and mineralogy of pellets from pilot-scale investigations. $<\mathrm{DL}$ indicates below instrument detection limit.

\begin{tabular}{|c|c|c|c|c|c|}
\hline \multirow{3}{*}{ Sample ID } & \multicolumn{4}{|c|}{ Uniformity } & \multirow{3}{*}{ Mineralogy } \\
\hline & Reactivity & $D_{50}$ & Coefficient & Specific surface area & \\
\hline & [] & [mm] & {$[-]$} & {$\left[\mathrm{m}^{2} / \mathrm{g}\right]$} & \\
\hline Dalum $_{\mathrm{RW}}$ & 7.39 & 1.15 & 1.22 & $0.0029 \pm 0.0008$ & NM \\
\hline de Beitel & 9.60 & NM & NM & $<\mathrm{DL}$ & Calcite \\
\hline Dalum $_{\mathrm{AF}}$ & 10.6 & 0.98 & 1.49 & $0.0021 \pm 0.0000$ & NM \\
\hline Brøndbyvester & 10.7 & 1.60 & 1.20 & $0.043 \pm 0.003$ & Calcite + quartz \\
\hline Brokilde & 11.2 & NM & NM & $0.050 \pm 0.008$ & Calcite + quartz \\
\hline Sønders $\varnothing$ & 11.3 & 1.1 & 1.26 & & Calcite + quartz \\
\hline Lindved & 11.8 & NM & NM & $0.18 \pm 0.007$ & NM \\
\hline Solhøj & 14.7 & 1.3 & 1.29 & $0.13 \pm 0.005$ & Calcite + quartz \\
\hline Lejre & 15.1 & 1.18 & 1.09 & $0.022 \pm 0.01$ & Calcite + quartz \\
\hline Regnemark & 15.8 & 1.32 & 1.17 & $<\mathrm{DL}$ & NM \\
\hline Hoogeveen & 15.9 & NN & NM & $<\mathrm{DL}$ & Calcite + quartz \\
\hline Marbjerg & & NM & NM & $0.023 \pm 0.007$ & Calcite + quartz \\
\hline Seppe & 17 & NM & NM & 0.0018 & Calcite \\
\hline Frederiksberg ${ }_{\mathrm{RW}, \mathrm{sar}}$ & 17.7 & 1.18 & 1.18 & 0.0005 & Calcite + quartz \\
\hline Havdrup & 20.2 & 1.25 & 1.13 & $0.016 \pm 0.009$ & Calcite + quartz \\
\hline Weesperkarspel & 22.1 & NM & NM & $<\mathrm{DL}$ & Calcite \\
\hline Frederiksberg ${ }_{A F, A I R}$ & 23.0 & 0.90 & 1.94 & $0.0066 \pm 0.0006$ & Calcite + quartz trace \\
\hline Frederiksberg ${ }_{\mathrm{RW}, \mathrm{AIR}}$ & 23.3 & 0.88 & 1.29 & $0.32 \pm 0.007$ & Calcite + quartz trace \\
\hline Frederiksberg ${ }_{R W, l i m e}{ }^{a}$ & 25.7 & 1.18 & 1.20 & 0.0010 & Calcite \\
\hline
\end{tabular}

a Only one replicate detected and hence no standard deviation

NM indicates not measured. 


\section{Figures}

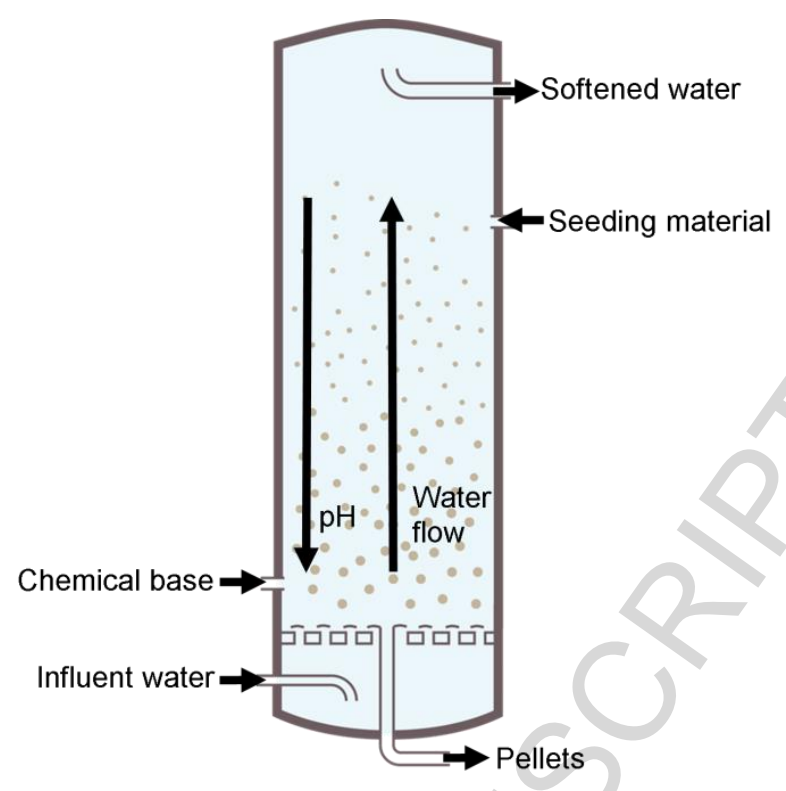

Figure 1: Conceptual figure of a pellet reactor. $\mathrm{pH}$ is highest in the bottom part of the reactor where the chemical base is dosed. 


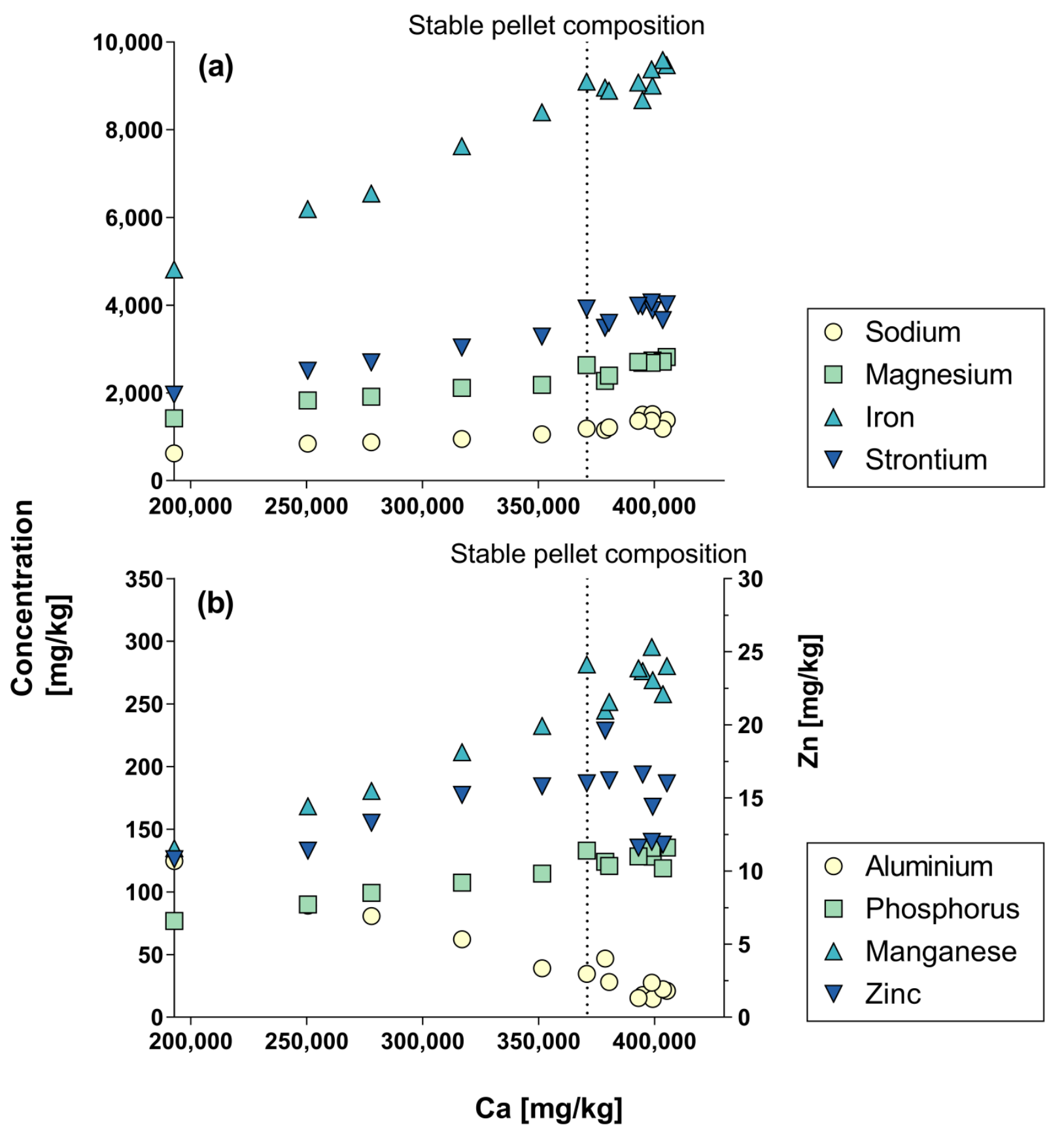

Figure 2: Concentration of sodium, magnesium, iron and strontium (a) and aluminium, phosphorus, manganese and zinc (b) in pellets as a function of pellet growth represented by the calcium concentration at Søndersø DWTP. 

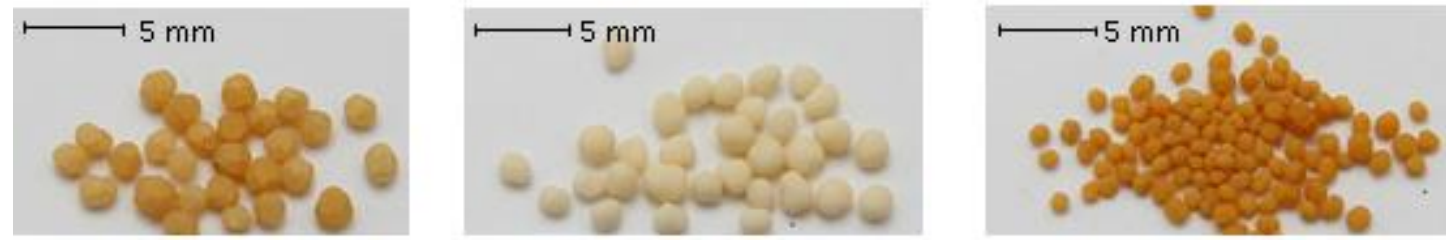

Figure 3: Pellet samples from Regnemark (after filtration), Dalum (after filtration) and Lindved (after aeration) appear visually different in terms of colour and particle size. 


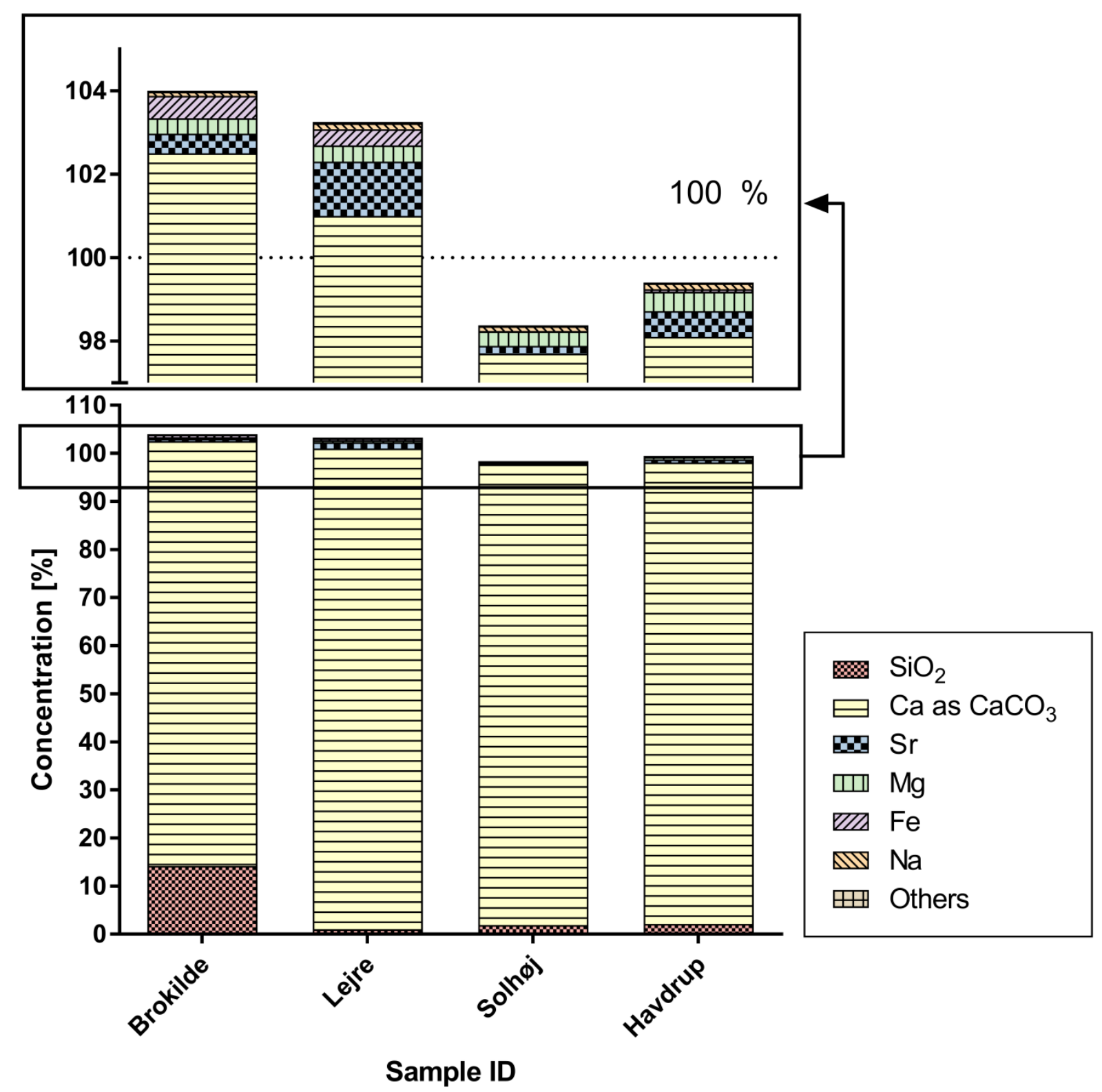

Figure 4: Composition of pellets including the seeding material $\left(\mathrm{SiO}_{2}\right)$ expressed as a percentage of the total mass. The Ca concentration was converted to $\mathrm{CaCO}_{3}$. 'Others' is the sum of $\mathrm{Mn}, \mathrm{P}, \mathrm{K}, \mathrm{Zn}, \mathrm{Al}, \mathrm{Ni}, \mathrm{Cu}, \mathrm{Li}, \mathrm{Cr}, \mathrm{Sn}, \mathrm{Pb}, \mathrm{As}$ and $\mathrm{Cd}$ concentrations. 

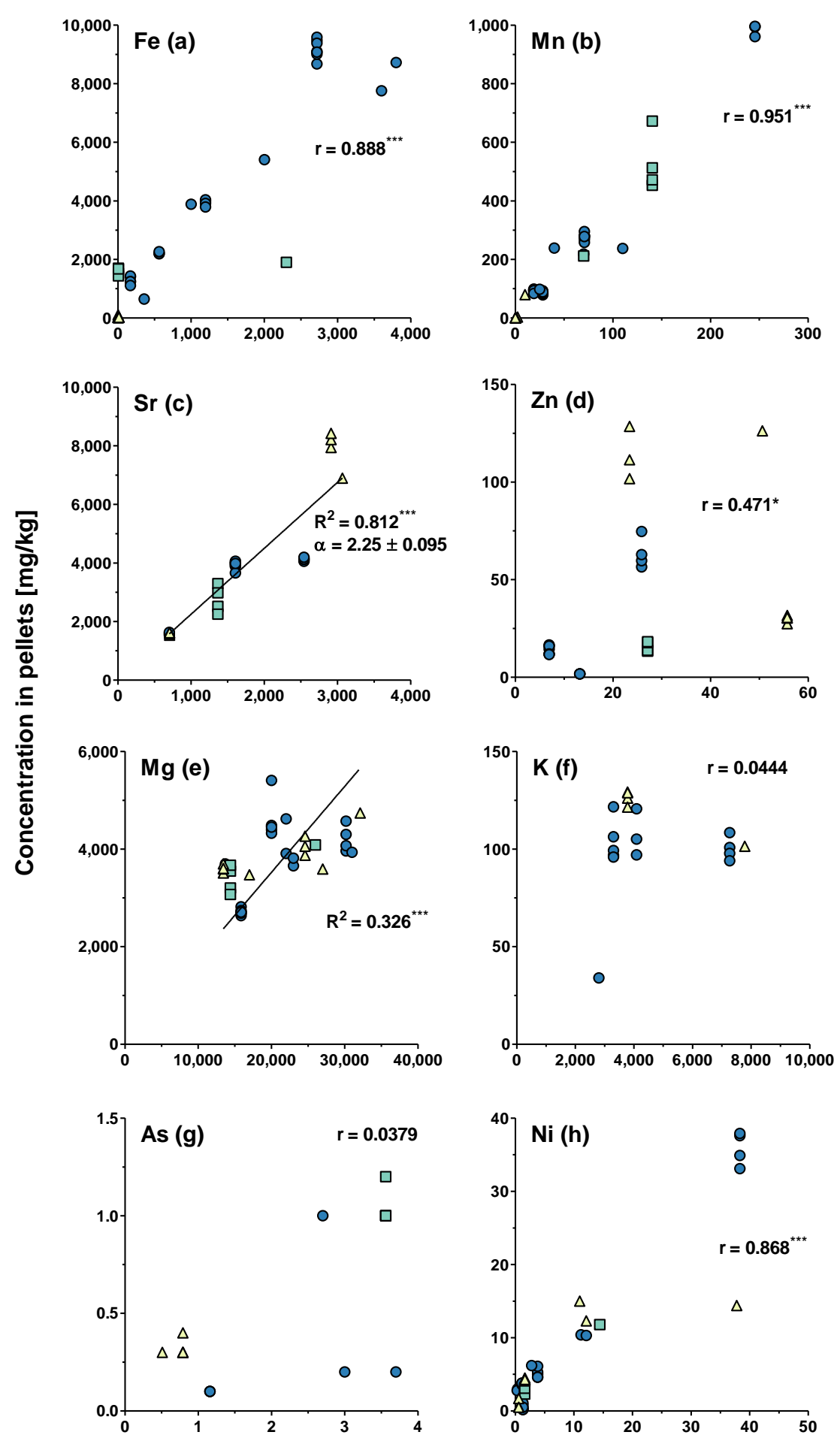

- Before aeration

$\square$ After aeration

$\triangle$ After filtration

\section{Concentration in water $[\mu \mathrm{g} / \mathrm{L}]$}

Figure 5: Correlation and linear regression analysis between the influent water concentration and the concentration measured in pellets. $R^{2}$ is the Pearson's correlation coefficient for normally distributed data and $r$ is the Spearman rank correlation coefficient for the remaining data. ${ }^{*}$ indicates a weak correlation and ${ }^{* * *}$ indicates a strong correlation. 

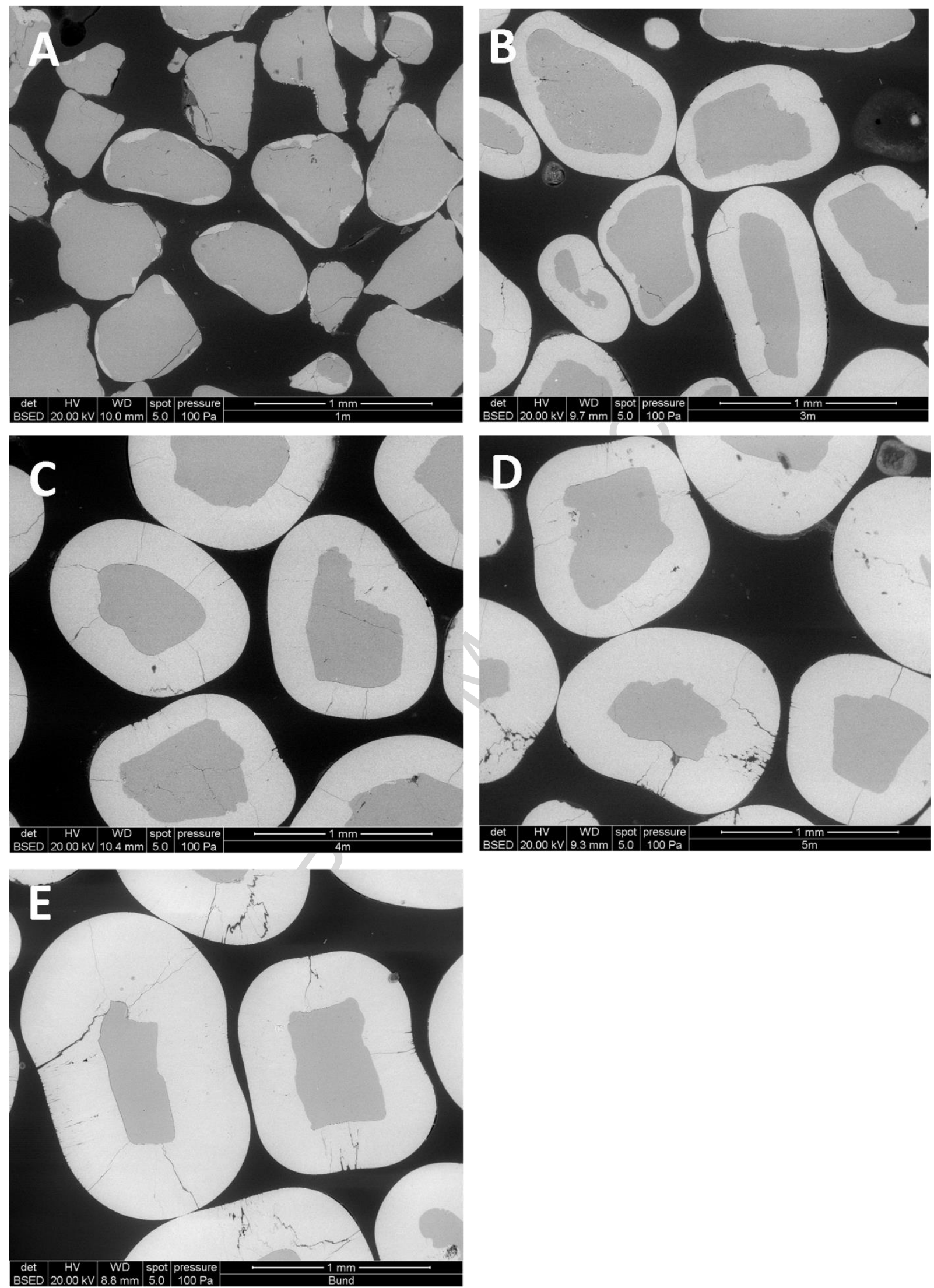

Figure 6: SEM of pellets from Dalum DWTP over the depth of the pellet reactor. A) $1 \mathrm{~m}$ below the water table, B) $3 \mathrm{~m}$, C) $4 \mathrm{~m}$, D) $5 \mathrm{~m}$, E) $5.7 \mathrm{~m}, 10 \mathrm{~cm}$ from the reactor bottom. 


\section{Graphical Abstract}

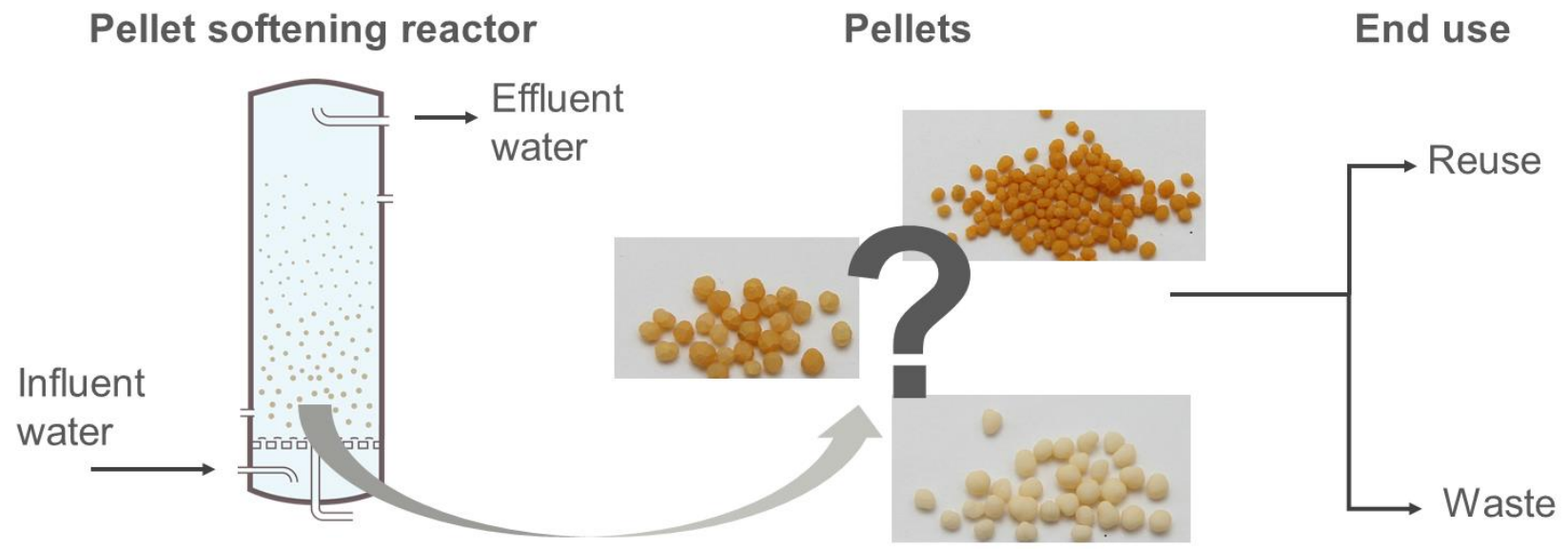




\section{Highlights}

- Better understanding of pellet characteristics can improve their reuse potentials

- The chemical composition of the pellets from pilot-scale investigations varied

- $\mathrm{Sr}, \mathrm{Fe}, \mathrm{Mg}, \mathrm{Mn}$ and $\mathrm{Ni}$ in pellets correlated with the influent water concentration

- Softening after rapid sand filtration results in higher pellet purity for Mn and Fe

- XRD analysis showed that all the investigated pellets crystallised as calcite 